\title{
PHYTOPLANKTON COMPOSITION IN RELATION TO HYDROCHEMICAL PROPERTIES OF TROPICAL COMMUNITY WETLAND, KANEWAL, GUJARAT, INDIA
}

\author{
NIRMAL KUMAR, J.I* - CINI OOMMEN \\ P.G. Department of Environmental Science and Technology, Institute of Science and \\ Technology for Advanced Studies and Research (ISTAR) \\ Vallabh Vidya Nagar, 388 120, Gujarat, India. \\ *Corresponding author \\ e-mail: istares2005@yahoo.com \\ (Received $28^{\text {th }}$ August 2008; accepted $8^{\text {th }}$ August 2011)
}

\begin{abstract}
A limnological investigation was carried out in Tropical Community Wetland, Kanewal, Gujarat, India from June 2007 to May 2008. Water quality parameters like temperature, pH, dissolved oxygen, secchi depth, total solids and total dissolved and suspended solids, free carbon dioxide, phenolphthalein alkalinity, total alkalinity, carbonates, bicarbonates, total hardness, calcium and magnesium hardness, chloride, phosphate, sulphate and nitrate and phytoplankton composition were investigated during the study period. Correlation coefficients were calculated among the various physicochemical variables and phytoplankton groups. Sulphate and nitrate both showed a positive correlation with phosphate. However, dissolved oxygen showed a negative correlation with phosphate, sulphate and nitrate at both the sites. Pearson Product Analysis for phytoplankton at the two sites was performed and it showed a high significance of Bacillariophyceae members between both the sites than other two groups. A total of 45 species were identified belonging to Cyanophyceae, Chlorophyceae and Bacillariophyceae but members of Euglenophyceae were found to be absent indicating a lesser degree of organic pollution. Moreover, species of Bacillariophyceae were recorded to be the most occurred group compared to others throughout the study which shows relatively unpolluted nature of wetland.
\end{abstract}

Keywords: Bacillariophyceae, Chlorophyceae, Cyanophyceae, wetland

\section{Introduction}

Wetland ecosystems are among the most productive ecosystems in the biosphere. Wetlands receive surface water inputs from streams (surface run off), precipitation, and overland flow and subsurface water inputs from surface infiltration, stream hyporheic zones, and ground water. These different inputs are important to wetland productivity because they contain markedly different quantities of transported nutrients (Stanley and Ward, 1997) and organic matter (Mann and Wetzel, 1995). Wetlands are recognized as ecosystems that harbor high biological diversity, provide sustenance for millions of people and face ongoing threats as results of human activities throughout the world (Gopal and Chauhan, 2001). As ecosystems, wetlands are highly volatile being particularly vulnerable to environmental fluctuations. Although wetland biodiversity constitutes a significant portion (e.g., 15-20\%), of the total biodiversity of the Indian Subcontinent (Gopal and Chauhan, 2001) studies of wetland ecosystems are limited (Tsai and Ali, 1997; Gopal and Zutshi, 1998; Gopal and Chauhan, 2001; de Graaf and Marttin, 2003). In recent years, increasing anthropogenic interventions influence in and around aquatic systems and their catchment areas have contributed to a larger extent towards deterioration of water quality leading to accelerated eutrophication. The hydrogeochemical characteristics and phytoplankton biomass of water bodies are not 
constant and fluctuate with seasonal variation as well degree of pollution (Prasad, 2006).

Phytoplanktons are integral components of freshwater wetlands, which significantly contribute towards succession and dynamics of zooplankton and fish (Payne, 1997). Community structure, dominance and seasonality of phytoplankton in tropical wetlands are highly variable and are functions of nutrient status, water level, morphometry of the underlying substrate and other regional factors (Gopal and Zutshi, 1998; Zohary et al. 1998; Agostinho et al. 2001). Phytoplanktons form the main producers of an aquatic ecosystem which control the biological productivity. They not only provide an estimation of standing crop but also represent more comprehensive biological index of the environmental conditions (Misra et al., 2001). Phytoplankton, which include bluegreen algae, green algae, diatoms, desmids and euglenoids etc are important among aquatic micro-flora. They form the basic link in the food chain of all aquatic animals (Misra et al., 2001). Many herbivores, mostly zooplankton, graze upon the phytoplankton thus, passing the stored energy to its subsequent trophic levels. The phytoplanktons float passively and spread uniformly and extend down to various depths, where hydrochemical properties influence the plankton population and its occurrence. Therefore, an attempt has been made to study "Phytoplankton Composition in Relation to Hydrochemical Properties of Tropical Community Wetland, Kanewal, Gujarat, India".

\section{Review of literature}

In recent past, studies on phytoplankton in relation to environmental conditions have been made by Demir and Kirkagac (2005). Muzaffar and Ahmed (2007) studied the effect of the flood cycle on the diversity and composition of phytoplankton community of a seasonally flooded Ramsar wetland in Bangladesh. Moreno-Ostos et al (2008) investigated spatial distribution of phytoplankton in a Mediterranean reservoir. Cardoso and Marques (2009) determined the short-term patterns derived from the interactions of wind-driven hydrodynamics and the plankton community in a large, shallow lake.

In India, studies on phytoplankton of lentic systems in relation to their environmental conditions have been made by Ganapathi (1941), Pandey et al. (2000). Mohan (1980) compared the values of organic carbon and planktonic biomass with that of dominant algal associations in two lakes of Hyderabad. Padhi (1995) in his studies on water chemistry and algal communities on the three freshwater ponds in and around Berhampur suggested revival methods using the algal communities as biological indicators. He recorded wide variations in $\mathrm{pH}$, dissolved oxygen, BOD, COD, phosphate and nitrates. Pandey et al. (2000) investigated the nutrient status and cyanobacterial diversity of tropical freshwater wetlands of Udaisagar and clearly indicated elimination of sensitive cyanobacterial species from the substations receiving urban industrial effluents. Pulle and Khan (2003) analyzed the qualitative and quantitative concepts of phytoplankton and recorded 43 species, of which 18 were Chlorophyceae, 10 Bacillariophyceae, 10 Cyanophyceae and 5 Euglenophyceae. Angadi et al. (2005) studied physico-chemical and biological status of aquatic bodies and recorded 39 species of algae from four classes.

In Gujarat state, Nandan (1983) studied the algal flora of polluted waters. Shaji (1989) and Jose (1990) evaluated the algae as pollution indicators in running waters. Rana and Nirmal Kumar (1992) and Nirmal Kumar et al. (2005, 2008) also studied 
physico-chemical characteristics of water and sediments, diversity of macrophytes and planktons of certain wetlands of Central Gujarat. Nirmal Kumar (1992) also prepared indices based on chemical properties in relation to planktons. However, there is no report on phytoplankton composition in relation to hydrochemical properties of tropical community wetland, Kanewal, Gujarat, India, so far. Looking into significance in mind, it is very much essential to carry out this interaction of plankton composition and nutrient status in this wetland, which is first of its kind in the state and as the wetland is also very much utilized by villagers of eight surrounding villages for their daily purposes.

\section{Materials and methods}

\section{Study area}

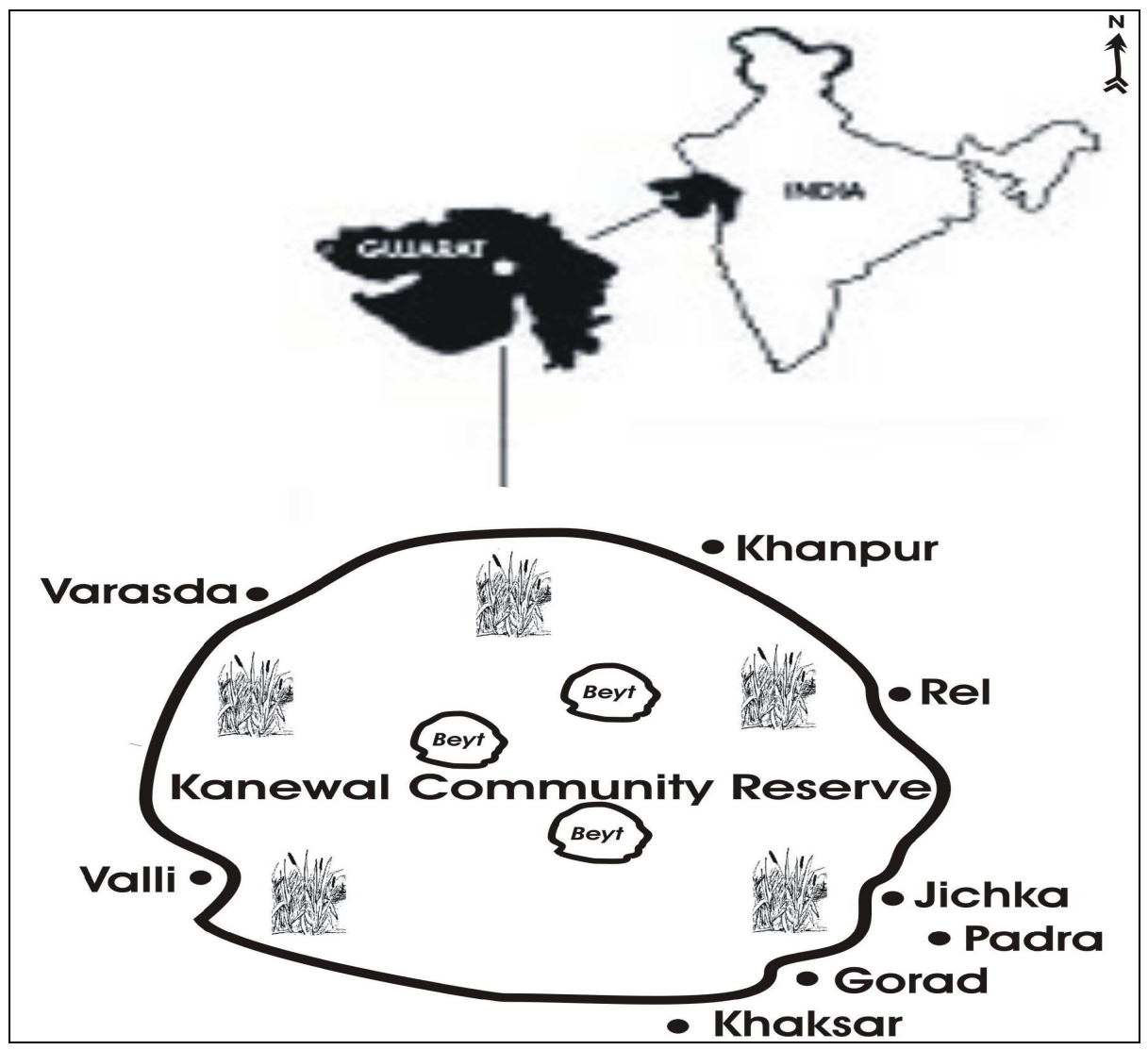

Figure 1. Location of Kanewal wetland, showing the eight villages around it

In the present study, a significant freshwater inland wetland habitat of the state, Kanewal Wetland of Anand District has been selected, which is an important waterstorage wetland and regularly harbours more than 20,000 water fowls during peak winter season (GSFD,2004); makes it eligible for RAMSAR convention. The population estimation of waterfowls of this wetland clearly signifies it as internationally important wetland (Koning and Koning-Raat, 1975; Scott, 1989) and the 'Wetlands of National Importance' (MoEF, 2005). Besides, it has already been recognized as Community Reserves by the Gujarat State Forest Department (GSFD, 2005). The water regime of Kanewal Community Reserve (KCR) supports around 130 species of 
waterfowls with an average of 20,000 waterfowls during peak winter months (Van Der Ven, 1987). Moreover, it is also one of the main water sources for Charotar, Bhal and Saurashtra regions of Gujarat, which supply water on the regular basis for irrigation and drinking and/or domestic purposes to the inhabitants of aforesaid regions through Saurashtra Pipeline Project (SPP). It is also cited in Asian Wetland Bureau, Kuala Lumpur, Malaysia (AWB and WWF-India, 1993) for Asian Waterfowls Census (AWFC).

Kanewal wetland is located between $22^{\circ} 35^{\prime} \mathrm{N}$ latitude and $72^{\circ} 36^{\prime}$ East longitude at an altitude between 14 to $15 \mathrm{~m}$ above the mean sea level, covering an area of $1500 \mathrm{ha}$. It is situated nearly 60kms from Anand, the Milk City of India and falls under 4- B Gujarat Rajwara region of Central Gujarat. It lies in a natural depression; surrounded by embankment with a circumference of about $15 \mathrm{~km}$ and comprises of three islands. This wetland is surrounded by eight villages (Fig. 1), which has a total population of 5000 and the villagers are completely dependent on this wetland for food, fodder and economy for their livelihood. Climatically, it experiences dry tropical monsoon, with an average annual rainfall of about $850 \mathrm{~mm}$ concentrated in the months of July, August and September. The other seasons include summer (March to June) followed by winter (November to December). However, pre-monsoon in the month of June 2007 has been recorded. The wetland harbours an abundant growth of aquatic vegetation e.g. Ipomoea aquatica, Marselia quadrifolia, Hydrilla verticillata, Vallisneria spiralis, Nymphea stellata, Nelumbo nucifera and plenteous beds of Typha angustata. Besides, it also harbours some resident avian species e.g. Moorhens, Egrets, Ibises, Lapwings, etc. and also attracts various migratory species of birds from remote countries like Europe, Russia, Siberia, China etc., which comprises waterfowls such as Coots, Plovers, Spoonbills, migratory ducks, etc during peak winter period. This wetland also supports a small fishery.

\section{Site 1}

This site is approached by main road, close to irrigation department and agriculture fields westwards. There is a permanent open well located adjacent to this site. The bank of this site is endowed with abundant beds of Typha angustata. It has a more open water surface, spanning more stretch of water and shallow basin. Due to shallow basin, the water level reaches hardly 9 to $10 \mathrm{ft}$. round the year. Although it attracts a good number of aquatic birds, the site is frequently seen being disturbed by the local inhabitants of the islands, situated opposite to the site. The site supports good vegetation such as Echinochloa colonum, Ipomoea aquatica, Nelumbo nucifera and Typha angustata. Due to presence of bank vegetation, birds like Egrets, Ibises, Herons and Moorhens prefer this site for foraging and roosting.

Site 2

This site is situated about $1 \mathrm{~km}$ from Valli village, adjacent by small 'kachcha' road and agriculture expansion towards west. Though the site is absolutely devoid of human settlements, it is frequently visited by 'Beyt' population (inhabitants) for boating and fishing. The mode of transport to this site is by bicycles and light vehicles. The bank of the site supports considerable growth of aquatic weed Typha angustata and Ipomoea aquatica. The average depth of water at this site is 18 to $20 \mathrm{ft}$ through out the year. There is a permanent water station and over-head water tank nearby this site for canalsing, providing water to local people for drinking and irrigation. The habitat is 
mainly dominated by aquatic macrophytes such as Echinochloa colonum, Hydrilla verticillata, Ipomoea aquatica, Nelumbo nucifera, Typha angustata and Vallisneria spiralis. Local people use the water mainly for irrigation and domestic purposes. Washing of clothes and utensils, bathing, cattle-wading and grazing is observed upto considerable extent at this site which contributes to non-point source of pollution.

\section{Sampling}

Surface water samples were collected in two litres polythene bottles from two sites in the wetland in the $2^{\text {nd }}$ week of every month from June 2007 to May 2008 and analyzed in the laboratory for important hydro-chemical properties. Physical parameters like $\mathrm{pH}$, temperature, secchi-disc transparency and dissolved oxygen (DO) were performed on the field. The rest of the parameters like total solids (TS), total dissolved solids (TDS), total suspended solids (TSS), free carbon dioxide, phenolphthalein alkalinity, total alkalinity, total hardness, calcium hardness, magnesium hardness, chloride, phosphate, sulphate and nitrate were analyzed in the laboratory. Samples were not collected in June and July due to heavy monsoon and flooding. Analysis of all the parameters was performed according to the methods described by APHA (1998) and Trivedy \& Goel (1986).

Phytoplankton samples were collected using phytoplankton nylon net, with sieve size of 10 microns and preserved in $4 \%$ formalin at the field and identified according to standard monographs- Cyanophyta (Desikachary, 1959), Fresh-Water Biology (Edmundson, 1963) and Indian Freshwater Microalgae (Anand, 1998) and books. Correlation coefficients were calculated among the various physico-chemical variables and phytoplankton groups. Pearson Product Analysis (PPA) was performed for phytoplankton at the two sites.

\section{Results}

\section{Physicochemical variables}

The hydro-chemical parameters of Kanewal wetland have been shown in Table 1, Fig. 2 for site 1 and Fig. 3 for site 2. Water temperature varied between $19^{\circ} \mathrm{C}$ and $31^{\circ} \mathrm{C}$ during the study period, maximum temperature of $31^{\circ} \mathrm{C}$ was achieved in the month of May 2008 at Site 2, while the minimum temperature was recorded in the month of January 2008 at Site 1. Values for $\mathrm{pH}$ remained close to neutral through out the investigated period but highest value of 7.8 was observed in the month of March 2008 at Site 1 and Site 2. Secchi depth varied between 115cms in August 2007 at Site 1 and $200 \mathrm{cms}$ in October 2007 at Site 2. Dissolved oxygen varied between $4.7 \mathrm{mgl}^{-1}$ and $11.27 \mathrm{mgl}^{-1}$ at Site 2 in May and January 2008, respectively. Total hardness ranged between $74 \mathrm{mgCaCO}_{3} \mathrm{l}^{-1}$ and $142 \mathrm{mgCaCO}_{3} \mathrm{l}^{-1}$, lowest being at Site 1 in August 2007 and highest at Site 2 in December 2007 and at Site1 in May 2008. The lowest and highest values of calcium hardness were measured as $31.5 \mathrm{mgCaCO}_{3}{ }^{-1}$ in December 2007 and $63.0 \mathrm{mgCaCO}_{3} 1^{-1}$ at Site 1 in January 2008, respectively. Magnesium hardness ranged between a minimum of $25.7 \mathrm{mgCaCO}_{3} \mathrm{l}^{-1}$ at Site 1 in August 2007 and a maximum of $102.1 \mathrm{mgCaCO}_{3} 1^{-1}$ at Site 2 in December 2007. The lowest concentration of chloride was measured as $25.56 \mathrm{mgl}^{-1}$ in September 2007 at Site 2 and highest as $52.54 \mathrm{mgl}^{-1}$ in March 2008 at Site 1 . The total phosphorus varied between 0.010 and $0.099 \mathrm{mgl}^{-1}$, the lowest in month of February 2008 at Site 1 and the maximum measured in May 2007 at Site 2. 
Table 1. Monthly variation in hydro-chemical parameters at Kanewal wetland from June 2007 to May 2008

\begin{tabular}{|c|c|c|c|c|c|c|c|c|c|c|c|c|c|}
\hline & 总 & 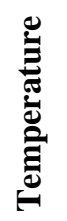 & 푤 & 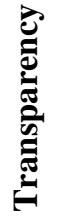 & $\tilde{\theta}$ & $\mathscr{W}$ & 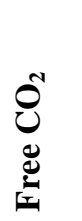 & $\overleftrightarrow{\Xi}$ & 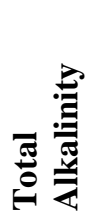 & 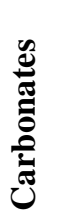 & 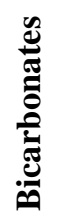 & 言总 & 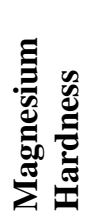 \\
\hline \multirow{2}{*}{ Jun } & S1 & - & - & - & - & - & - & - & - & - & - & - & - \\
\hline & S2 & - & - & - & - & - & - & - & - & - & - & - & - \\
\hline \multirow{2}{*}{ Jul } & S1 & - & - & - & - & - & - & - & - & - & - & - & - \\
\hline & S2 & - & - & - & - & - & - & - & - & - & - & - & - \\
\hline \multirow{2}{*}{ Aug } & S1 & 26 & 7.1 & 115 & 20 & 20 & 0 & 12 & 62 & 24 & 38 & 48.3 & 25.7 \\
\hline & $\mathrm{S} 2$ & 27 & 7.2 & 139 & 40 & 20 & 0 & 12 & 98 & 24 & 74 & 49.3 & 54.7 \\
\hline \multirow{2}{*}{ Sep } & S1 & 28 & 7.4 & 130 & 20 & 20 & 0 & 8 & 76 & 16 & 60 & 46.2 & 37.8 \\
\hline & S2 & 28 & 7.6 & 150 & 60 & 40 & 13.2 & 0 & 86 & 0 & 86 & 45.6 & 58.4 \\
\hline \multirow{2}{*}{ Oct } & S1 & 24 & 7.1 & 126 & 120 & 60 & 0 & 10 & 84 & 20 & 64 & 48.3 & 43.7 \\
\hline & $\mathrm{S} 2$ & 26 & 7.6 & 200 & 100 & 60 & 17.6 & 0 & 98 & 0 & 98 & 58.8 & 51.2 \\
\hline \multirow{2}{*}{ Nov } & S1 & 22 & 7 & 133 & 20 & 20 & 0 & 6 & 80 & 12 & 68 & 48.3 & 49.7 \\
\hline & $\mathrm{S} 2$ & 25 & 7 & 196 & 100 & 40 & 0 & 6 & 96 & 12 & 84 & 48.3 & 61.7 \\
\hline \multirow{2}{*}{ Dec } & S1 & 20 & 7.2 & 120 & 100 & 20 & 0 & 12 & 82 & 24 & 58 & 31.5 & 76.5 \\
\hline & S2 & 22 & 7.2 & 170 & 140 & 20 & 26.4 & 0 & 128 & 0 & 128 & 39.9 & 102.1 \\
\hline \multirow{2}{*}{ Jan } & S1 & 19 & 7.4 & 137 & 80 & 40 & 17.6 & 0 & 170 & 0 & 170 & 63 & 65 \\
\hline & S2 & 20 & 7.6 & 156 & 100 & 40 & 0 & 10 & 150 & 20 & 110 & 59.3 & 46.7 \\
\hline \multirow{2}{*}{$\mathrm{Feb}$} & S1 & 20 & 7.3 & 140 & 120 & 20 & 0 & 8 & 96 & 16 & 80 & 46.2 & 91.8 \\
\hline & S2 & 21 & 7.3 & 161 & 100 & 40 & 0 & 4 & 86 & 8 & 78 & 42 & 72 \\
\hline \multirow{2}{*}{ Mar } & S1 & 22 & 7.8 & 136 & 120 & 20 & 0 & 4 & 80 & 8 & 72 & 39.9 & 86.1 \\
\hline & $\mathrm{S} 2$ & 21 & 7.8 & 153 & 80 & 40 & 0 & 0 & 96 & 0 & 96 & 44.1 & 59.9 \\
\hline \multirow{2}{*}{ Apr } & S1 & 25 & 7.7 & 125 & 130 & 20 & 0 & 8 & 140 & 16 & 124 & 45.7 & 93.3 \\
\hline & S2 & 24 & 7.8 & 141 & 110 & 25 & 0 & 6 & 108 & 12 & 96 & 49.5 & 75.5 \\
\hline \multirow{2}{*}{ May } & S1 & 29 & 7.8 & 119 & 135 & 35 & 0 & 8 & 154 & 16 & 138 & 47.8 & 94.2 \\
\hline & $\mathrm{S} 2$ & 31 & 7.7 & 130 & 90 & 30 & 0 & 8 & 114 & 16 & 98 & 52.4 & 77.6 \\
\hline
\end{tabular}

All values are in $\mathrm{mgl}^{-1}$ except temperature $\left({ }^{\circ} \mathrm{C}\right), \mathrm{pH}$ and transparency (centimeters)

*Samples not collected in June and July due to heavy monsoon and flooding

Sulphate concentration ranged between a lowest of $6.211 \mathrm{mgl}^{-1}$, observed at Site 1 in September 2007 and highest of $27.029 \mathrm{mgl}^{-1}$ at Site 2 in May 2008. The lowest and highest values of nitrate were measured as $0.149 \mathrm{mgl}^{-1}$ in September 2007 at Site 1 and $0.476 \mathrm{mgl}^{-1}$ in May 2008 at Site 2 respectively. The values of hydrochemical properties were higher at Site 2 as compared to Site 1, probably due to vicinity to the villages, addition of village wastes, interference of cattle, bathing and washing.

Correlation coefficient showed that at Site 1, temperature and $\mathrm{pH}$ correlated positively (0.0429). Phosphate also correlated positively with temperature (0.1162). Sulphate and nitrate both showed a positive correlation with phosphate $(0.6098$ and 0.2695 respectively). However, DO showed a negative correlation with phosphate $(-0.2978)$, sulphate $(-0.660)$ and nitrate $(-0.850)$. At Site 2 , temperature and DO showed a positive correlation (0.033). Phosphate also correlated positively with temperature (0.613). Unlike Site 1, sulphate and nitrate correlated negatively with phosphate $(-0.0134)$ and $(-0.472)$, at Site 2 . DO showed a negative correlation with phosphate $(-0.476)$, sulphate $(-0.766)$ and nitrate $(-0.472)$. 

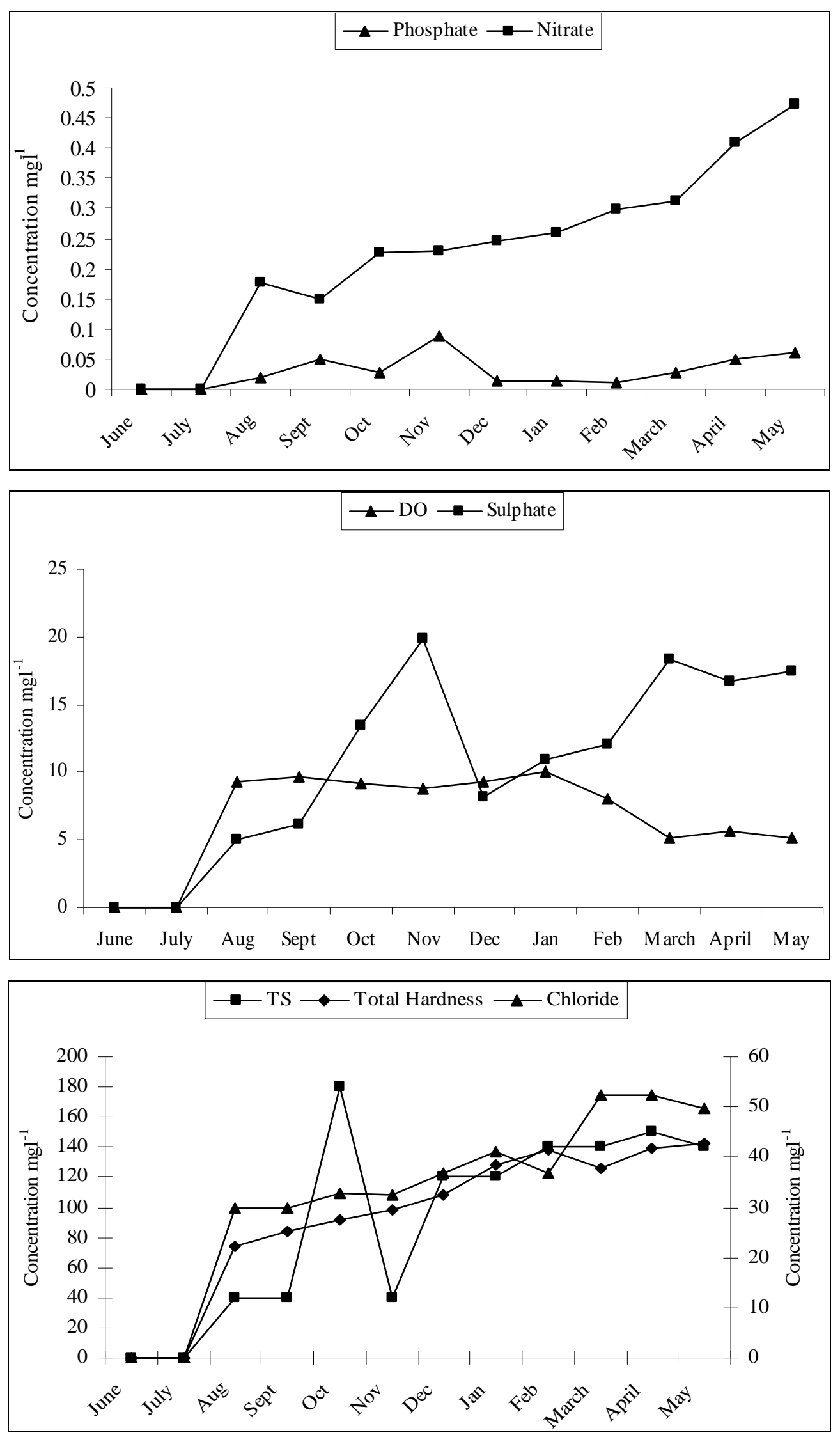

Figure 2. Monthly variation in hydro-chemical parameters at Kanewal wetland from June 2007 to May 2008., Site 1

APPLIED ECOLOGY AND ENVIRONMENTAL RESEARCH 9(3): 279-292. http://www.ecology.uni-corvinus.hu • ISSN 15891623 (Print) • ISSN 17850037 (Online) (c) 2011, ALÖKI Kft., Budapest, Hungary 

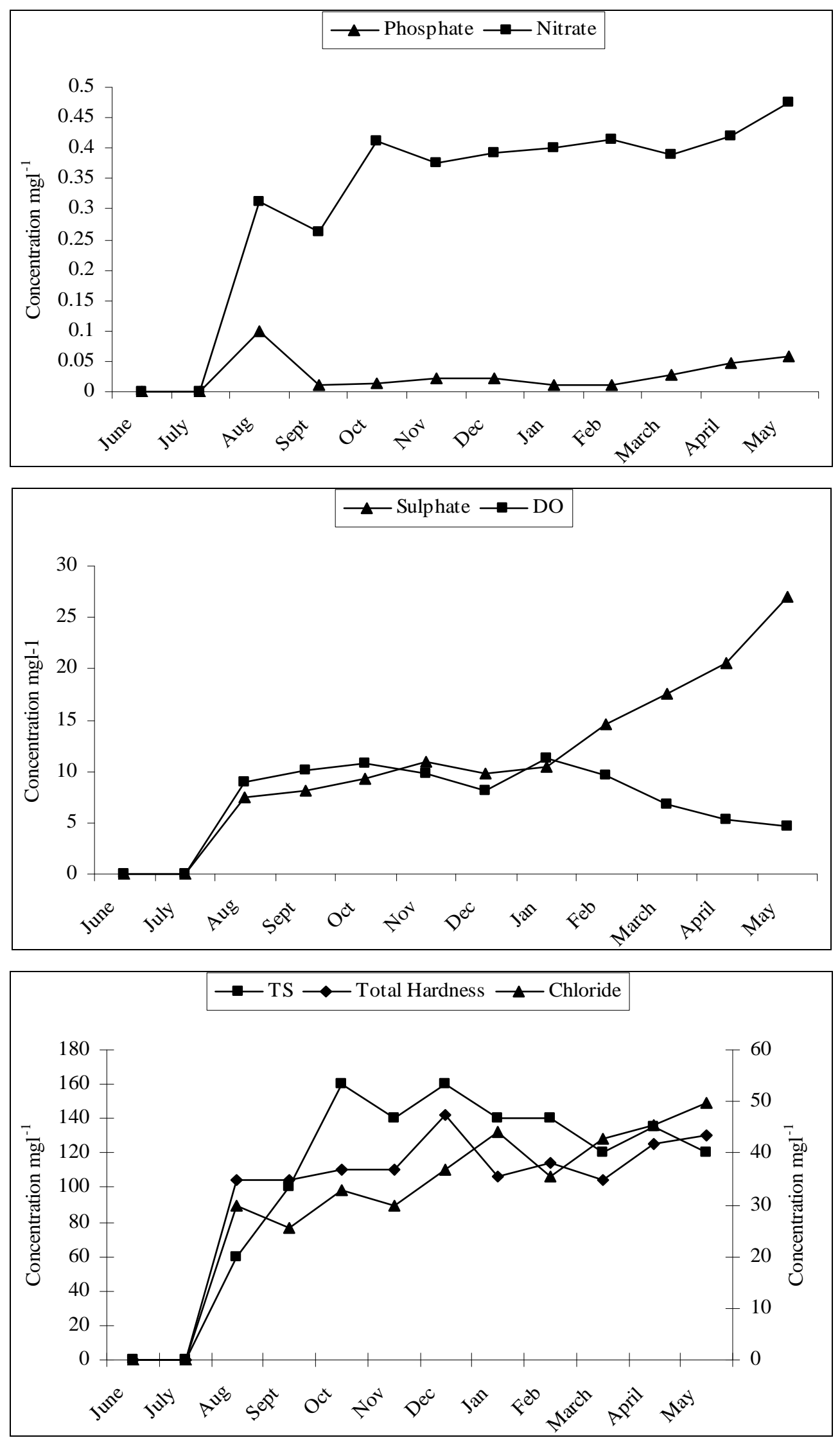

Figure 3. Monthly variation in hydro-chemical parameters at Kanewal wetland from June 2007 to May 2008., Site 2

APPLIED ECOLOGY AND ENVIRONMENTAL RESEARCH 9(3): 279-292. http://www.ecology.uni-corvinus.hu • ISSN 15891623 (Print) • ISSN 17850037 (Online) (c) 2011, ALÖKI Kft., Budapest, Hungary 


\section{Phytoplankton community}

The study of the phytoplankton sampled in Kanewal wetland showed 45 species (Table 2). The phytoplankton assemblage was represented by three classes of algae viz. Cyanophyceae, Chlorophyceae and Bacillariophyceae: 18 taxa were Cyanophytes, 17 were Chlorophytes and 9 were diatoms. The wetland showed the post monsoon months dominated by the Chlorophytes whereas; Bacillariophytes dominated the winter months at both the sites. Some species occurred in all the months at both the sites during the sampling period viz. Merismopoedia convulata, Oscillatoria princeps, Spirulina princeps, Cosmarium monomazum, Cosmarium granatum, Desmidium sp., Euastrum sp. and Mastogloia vasta.

Table 2. Occurrence of phytoplankton species at both the sites at Kanewal Wetland

\begin{tabular}{|c|c|c|}
\hline Cyanophyceae & Chlorophyceae & Bacillariophyceae \\
\hline Gloeocapsa atrata & Chlorella sp. & Cyclotella sp. \\
\hline Gloethece rupestris & Pediastrum duplex & Cymbella sp. \\
\hline Chroococcus indicus & Coelastrum cambricum & Gomphonema sp. \\
\hline Chroococcus minor & Scendesmus quadricauda & Nitzschia sp. \\
\hline Microcystis aeruginosa & Scendesmus armatus & Navicula sp. \\
\hline Merismopoedia minima & Ankistrodesmus falcatus & Fragillaria sp. \\
\hline M. glauca & Zygnema inisigne & Mastogloia vasta \\
\hline M. elegans & Spirogyra sp. & M. elliptica \\
\hline M. convulata & Closterium libleinii & Achnanthes sp. \\
\hline M. punctata & Staurastrum orbiculare & \\
\hline Arthrospira platensis & S. sp. & \\
\hline Spirulina princeps & Euastrum spinulosum & \\
\hline S. laxissima forma major & E. gemmatum & \\
\hline Oscillatoria limosa & Cosmarium monomazum & \\
\hline O. princeps & Cosmarium granatum & \\
\hline Lyngbya porphyrosiphonis & Spondylosium moniliforme & \\
\hline Anabaena sphaerica & Desmidium sp. & \\
\hline Nostoc muscorum & Gloeotaenium loitlesbergianum & \\
\hline
\end{tabular}

The total density of phytoplankton was found maximum during February month while it was minimal during rainy months (Fig 4).

The class Cyanophyceae was represented by 18 species belonging to 11 genera. The members of family Chroococcaceae were among the most abundant in the class. The family was represented by the species of genera Merismopoedia, Chroococcus, Gleocapsa and Gloethece. Cyanophycean community appeared in greater numbers when phosphate, sulphate and nitrate concentrations of waters were comparatively moderate to higher, during winter and summer months.

The class Chlorophyceae was represented by maximum genera. Among the members, the representatives of family Desmediaceae were the abundant and consisted of genera Cosmarium, Closterium, Staurastrum, Euastrum, Desmidium and Spondylosium. Desmediaceae was followed by Zygnemaceae consisting of genera Zygnema and Spirogyra. The other members of the class were Scendesmus, Pediasrtrum and Ankistrodesmus. The community of Chlorophyceae was rich during high DO and comparatively low chemical status, especially during winter months. 

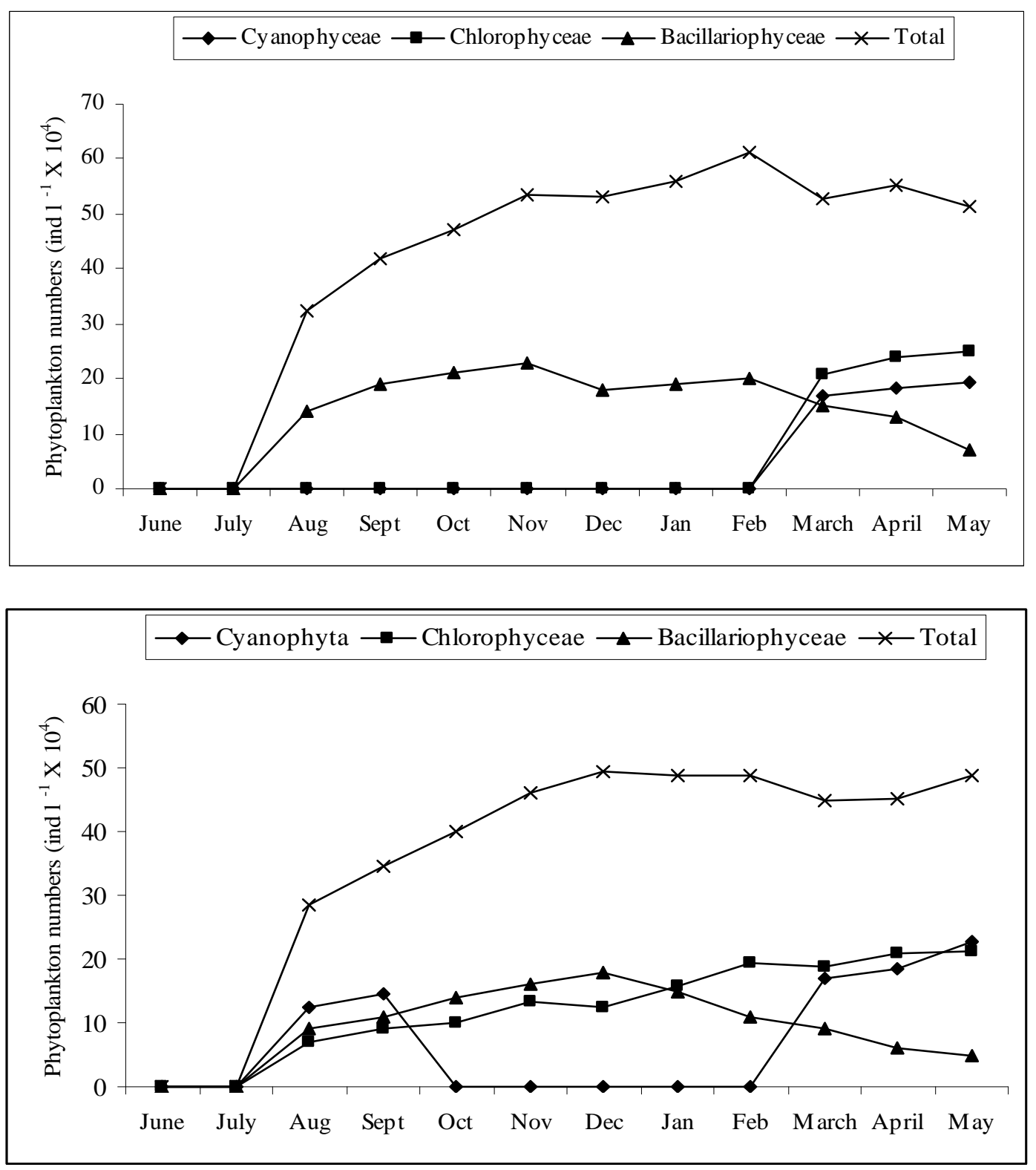

Figure 4. Monthly variation in phytoplankton number at Kanewal wetland from June 2007 to May 2008., Site 1 (upper) and Site 2

The class Bacillariophyceae being the most dominant was represented by the genera, Fragillaria, Navicula, Achnanthes, Mastogloia, Cyclotella, Cymbella, Gomphonema and Nitzschia. However, except Navicula species, most of the members appeared round the year particularly during winter because of high DO and low nutrient condition of waters and their community became smaller as the summer progressed at both the sites. The correlation analysis of the important parameters with the phytoplankton showed a positive correlation with DO, a value of 0.377 at Site 1 and 0.187 at Site 2 (Table 3). Sulphate showed a positive correlation with phytoplankton at Site 2 (0.440). Phosphate and nitrate showed a negative correlation at both the sites (-0.127) at Site 1 and $(-0.562$ at Site 2). Sulphate showed a negative correlation at Site 1 (-0.593). Pearson Product Analysis for phytoplankton showed a high significance of Bacillariophyceae members between both the sites than other two groups. 
Table 3. Correlation Coefficient Analysis of important chemical parameters with total phytoplankton species

\begin{tabular}{l|c|c}
\hline Hydro-chemical Properties & Site 1 & Site 2 \\
\hline Phosphate & -0.122 & -0.562 \\
Sulphate & -0.594 & 0.440 \\
Dissolved Oxygen & 0.378 & 0.187 \\
Nitrate & 0.703 & 0.756 \\
\hline
\end{tabular}

\section{Discussion}

Diversity of plankton population is fairly dependent on quality of water and climatic factors. Phytoplankton diversity and productivity are strongly related to water quality (e.g., Moss, 1988) as well as to biotic factors (Scheffer, 1998). Singh (1965) stated that temperature, $\mathrm{pH}$, alkalinity and phosphate have been emphasized to be significant factors for controlling distribution of Cyanophyceae which is also corroborated with the present study. Alkalinity range of 50 to $110 \mathrm{mg} / \mathrm{L}$ has been reported as optimum for the Cyanophyceae (Jackson 1971) which coincide with current findings where alkalinity is within the range. Tripathy \& Panday (1990) Rana and Nirmal Kumar (1993), Hegde and Sujata (1997) and Nirmal Kumar et al. (2005) reported that high water temperature, phosphate, nitrate, low $\mathrm{DO}$ and $\mathrm{CO}_{2}$ supported the growth of Chlorophyceae and Diatoms. Harish (2002) concluded that phosphates, nitrates and nitrites control the growth of Chlorophyceae and Diatoms in lentic waters. Perhaps this could be the reason in the present study, species of Chlorophyceae and Diatoms were found abundant, which was having phosphate, nitrate and high DO concentrations at both sites.

Patrick (1973) observed that the acidic waters do not support an abundance of Bacillariophyceae, while in alkaline waters with $\mathrm{pH}$ above 8.0 , their density is more. In the current investigation, $\mathrm{pH}$ was found to be in the neutral range $(7.0-8.0)$ supporting a good population of the diatoms. Zafar (1964) and Singh \& Swarup (1979) reported that higher concentrations of calcium promote the growth of diatoms but Harish (2002) pointed out that there is no relationship between abundance of diatoms and calcium. In Kanewal, the Bacillariophyceae were the most dominant and occurred through out the period of study. Moreover, DO content was found to be considerably high in colder months. Reid (1961) stated that the solubility of oxygen in water increased by lowering the temperature, that is, solubility of oxygen in water was known to be affected inversely by the rise in temperature (Moss 1988). Nitrate showed lower values but an increase in its concentration was observed in winter months. This may be attributed to inflow of rain water and partly by decomposition of macrophytes. The plankton community, on which the whole aquatic population depends, is largely influenced by interaction of a number of hydro-chemical factors like low DO, moderate sulphate, nitrate, phosphate and other characters. Moss, (1988) and Rana et al (1995) showed that a number of physico-chemical and biological factors acting simultaneously must be taken into consideration in understanding the diversity of plankton population. The present study ensures that variation in the abundance of plankton can be best explained when environmental factors jointly influence. Thus, it may be concluded that the composition of phytoplankton is dependent on different abiotic factors either directly or indirectly. 
Acknowledgements. Authors are thankful to Mr. Jagdeesh Rao, Executive Director, Mr. Subrat, Scientific officer, Foundation for Ecological Security, Anand, Gujarat for financial assistance of this research project and Ms Kiran Kumari, for her cooperation during field visits.

\section{REFERENCES}

[1] Agostinho A.A., Thomaz S.M., Minte-Vera C.V., Winemiller K.O. (2001): Biodiversity of the Parana River floodplain. - In: Gopal B, Jumk WJ, Davis JA (eds) Biodiversity in wetlands: assessment, function and conservation, vol 1., Backhuys Publishres, Leiden, pp 89-118.

[2] American Public Health Association (APHA) (1998): Standard methods for the examination of water and sewage. $-20^{\text {th }}$ edn. Washington DC

[3] Anand N. (1998): Indian freshwater microalgae. - Gajendra Singh Gahlot

[4] Angadi S.B., Shidda Mallaiah N., Patil P.C. (2005): Limnological studies of Papanash pond, Bidar, Karnataka. - J. Environ. Bio. 26: 213-216.

[5] AWB and WWF-India (1993): Directory of Indian Wetlands. - Published by Asian Wetland Bureau, Kuala Lumpur, Malaysia and WWF-India, New Delhi

[6] Cardoso Luciana de Souza and Marques David da Motta (2009): Hydrodynamics-driven plankton community in a shallow lake. - Aquatic Ecology 43(1): 73-84

[7] Davis C.C. (1955): The marine and freshwater plankton. - Michigan State Univ. Press, East Lansing, USA

[8] de Graaf G.J., Marttin F. (2003): Mechanisms behind changes in fish biodiversity in the floodplains of Bangladesh. - Wetlands Ecol Manage 11: 273-280.

[9] Demir Nilsun, Kirkagac Mine U. (2005): Plankton composition and water quality in a pond of spring origin in Turkey. - Limnology 6:189-194.

[10] Desikachary T.V. (1959): Cyanophyta. - Indian Council of Agriculture Research, New Delhi

[11] Devi Anitha U., Charya Singara M.A. (2007): Phytoplankton in Lower Manair Dam and Kakatiya Canal, Karimnagar, Andhra Pradesh. - Nature Environment and Pollution Technology 6(4):643-648.

[12] Edmondson W.T. (1963): Freshwater biology. -John Wiley \& Sons, Inc

[13] Ganapathi S.V. (1941): Studies on the chemistry and biology of ponds in the Madras City: Seasonal changes in the physical and chemical conditions of a garden pond containing aquatic vegetation. - J. Madras Univ. 13: 55-59.

[14] Gonzalves E.A., Joshi D.B. (1946): The seasonal succession of the algae in the tank of Bandra. - J. Bombay Nat. Hist. Soc. 46: 154-176.

[15] Gopal B., Chauhan M. (2001): South Asian wetlands and their diversity: the role of monsoons. - In: Gopal B, Junk WJ, Davis JA (eds) Biodiversity in wetlands: assessment, function and conservation, vol 2.,Backhuys Publishers, Leiden, pp 257-276.

[16] Gopal B., Zutshi D.P. (1998): Fifty years of hydrobiological research in India. Hydrobiologia 384:267-290.

[17] Goutam Ranjan, Singh N.P., Singh R.B. (2007): Physico-chemical characteristics of Ghariyarwa pond of Birganj, Nepal in relation to growth of phytoplankton. - Nature Environment and Pollution Technology 6(4): 629-632

[18] GSFD (2004): Waterfowl Census (Winter 2004) Final Technical Report. - Gujarat State Forest Department, Gandhinagar, Gujarat

[19] GSFD (2005): Six Wetlands now at par with Chilka. A Proposition by Chief Wildlife Warden - Gujarat State Forest Department, Gandhinagar, Gujarat

[20] Harish (2002): Limnology of ponds and lakes of Mysore, Karnataka, India. - Ph.D. Thesis, Mysore University 
[21] Hegde G.R., Sujata T. (1997): Distribution of planktonic algae in three freshwater lentic habitats of Dharwad. - Phykos 36(1-2): 49-53

[22] Jackson D.F. (1971): Comparative studies on phytoplankton photosynthesis in relation to total alkalinity. - Ver. Int. Yer.- Limnol. 14: 125-133.

[23] Jose J. (1990): Ecological studies of certain polluted rivers of Gujarat

[24] Koning F.J., Koning-Raat M.J. (1975): IWRB Mission to India. January/February 1975 Technical Report. - International Waterfowl Research Bureau (IWRB)

[25] Mann C.J., Wetzel R.G. (1995): Dissolved organic carbon and its utilization in a riverine wetland ecosystem. - Biogeochemistry 31: 99-120.

[26] Misra S.M., Pani S., Bajpai A., Bajpai A.K. (2001): Assessment of tropic status by using Nygaard index with reference to Bhoj wetland. - Poll. Res. 20(2): 147-153.

[27] MoEF (2005): Gujarat: Six new 'Wetlands of National Importance'. - Protected Area Update. 54: 6

[28] Mohan K.S. (1980): Limnology of the Osman Sagar and Mir Alam lakes. - Ph.D Thesis, Osmania Univ., Hyderabad, India

[29] Moreno-Ostos, E., Cruz-Pizarro, L., Basanta, A., Glen, G.D. (2008): The spatial distribution of different phytoplankton functional groups in a Mediterranean reservoir. Aquat Ecol 42: 115-128.

[30] Moss Brain (1988): Ecology of freshwaters: Man and medium. $-2^{\text {nd }}$ ed., Oxford, Blackwell Scientific Publ., London, UK

[31] Muzaffar Sabir B., Fakhruddin A.A. (2007): The effects of the flood cycle on the diversity and composition of the phytoplankton community of a seasonally flooded Ramsar wetland in Bangladesh. - Wetlands Ecol Manage 15: 81-93.

[32] Nandan S.N. (1983): Algal flora of polluted waters of Gujarat state

[33] Nirmal Kumar J.I., Kumar, R.N., Bhatt, I. (2005): Study of Cultural Eutrophication in relation to the plant diversity of Wetland Rathreshwar in central Gujarat. - In: Aquatic Biodiversity Scenario. Discovery Publication House, New Delhi. Pp. 152-170.

[34] Nirmal Kumar J.I., Hiren Soni, Kumar R.N. (2008): Patterns of site-specific variation of waterfowl community, abundance and diversity in relation to seasons in Nal Lake Bird Sanctuary, Gujarat, India. - International J Global Bird Biogeography 8: 1-20.

[35] Nirmal Kumar J.I. (1992): Trophic status of certain lentic waters in Kheda district Gujarat, India. - In: R.K. Trivedy (ed). Ecology and Pollution of lakes and reservoirs, Asish Publishers, New Delhi. 203-222

[36] Padhi M. (1995): Algal environment of polluted and unpolluted freshwaters ponds. - In: Kargupta A.N., Siddiqui EN (eds). Algal Ecology: An overview., International Book Distributor, Dehradun, India

[37] Pandey J., Usha P., Tyagi H.R. (2000): Nutrient status and cyanobacterial diversity of a tropical freshwater lake. - J. Env. Bio. 21: 133-138.

[38] Patrick R. (1973): Use of algae, especially diatoms in assessment of water quality. - In: Biological Methods of Assessment of Water Quality. ASIM/STP, 76-95

[39] Prasad V. (2006): Cyanobacterial distribution of Birganj, Nepal. - Int. J. Mendel 23(3-4): 125-126.

[40] Pulle J.S., Khan A.M. (2003): Phytoplanktonic study of Isapur dam water. - Eco. Env. Conser. 9: 403-406.

[41] Rana B.C., Nirmal Kumar J.I. (1992): Macrophytes and Nutrient study of two wetlands of Guajrat, India. - International Journal Ecology and Environmental Science.18: 195-202.

[42] Ravikumar M., Manjappa S., Kiran B.R., Puttaiah E.T. (2006): Phytoplankton periodicity in relation to abiotic factors in Kulahalli tank near Harapanahalli, Karnataka. - Nature Environment and Pollution Technology 5(1): 157-161.

[43] Reid G.K. (1961): Ecology of inland waters and estuaries. - Reinhold Publication Corporation, New York, USA 
[44] Scheffer M. (1998): Ecology of Shallow Lakes. - Chapman \& Hall, London

[45] Scott R. (Ed.) (1989): The Asian Directory of Wetlands. - IUCN Glands, Switzerland

[46] Shaji C. (1990): Studies in algal flora and ecology of some polluted waters in Gujarat

[47] Singh B.N., Swarup K. (1979): Limnological studies of Suraha lake (Ballia): The periodicity of phytoplankton. - J. Indian. Bot. Sco. 58: 319-329.

[48] Singh M. (1965): Phytoplankton periodicity in a small lake near Delhi. I. - Phykos, 4: 6168.

[49] Stanley E.H., Ward A.K. (1997): Inorganic nitrogen regimes in an Albama wetland. Journal of the North American Benthological Society 16:820-832

[50] Tripathy A.K., Pandey S.N. (1990): Water pollution. - Ashish Publishing House, pp 1326.

[51] Trivedy R.K., Goel P.K., Trisal C.L. (1987): Practical methods in ecology and environmental science. - Enviro Media

[52] Tsai C., Ali Y. (1997): Openwater fisheries of Bangladesh. - The University Press Limited, Dhaka

[53] Van Der Ven, J. (Ed.) (1987): Asian Waterfowl 1987: Midwinter Bird Observations in Some Asian Countries. - Slimbridge, UK

[54] Zafar A.R. (1959): An apparatus for sampling water and mud from the deeper strata of lakes. - J. I. B. Soc. 38(1): 109-113.

[55] Zafar A.R. (1964): On the ecology of the Algae in certain fish ponds of Hyderabad, India, Physico-chemical complexes. - Hydrobiologia 23: 179-195.

[56] Zohary T., Fishbein T., Kaplan B., Pollingher U. (1998): Phytoplankton-metaphyton seasonal dynamics in a newly-created subtropical wetland lake. - Wetlands Ecol Manage 6:133-142 